УДК 1(091)

DOI 10.35423/2078-8142.2019.3-4.08

\author{
O. С. Легеза, \\ аспірантка кафедри філософії \\ Дніпровського начіонального університету ім. О. Гончара \\ м. Дніпро, Україна \\ e-mail:volansandvela@gmail.com \\ ORCID: https://orcid.org/0000-0002-0329-4329
}

\title{
КОНЦЕПЦІЯ МІФУ У ПРАЦЯХ М. ЕЛІАДЕ
}

У статті досліджено конщепиію міфу у прачях М. Еліаде. Визначено, що М. Еліаде розглядає міф як невід'ємний структурний компонент реальності культури, відмежовуючи його від «несправжніх» оповідей. Надана характеристика основних складових частин міфу у праиях М. Еліаде. Доведено, щчо, згідно з конщепџією М. Еліаде, міф повертає людину до витоків світу, відповідає ї̈ екзистенційним запитам, надає людині необхідні паттерни поведінки. Відзначається, щуо навіть після процесів деміфологізаиії, міф, яким його бачить румунський мислитель, продовжує відігравати ключову роль у житті людини, оскільки сприяє створенню важливих традииій, політичних та релігійних течій, літературних творів і витворів мистецтвва, а на індивідуальному рівні проявляється у вигляді фантазій та сновидінь.

Ключові слова: М. Еліаде, міф, міфологія, міфологічний дискурс, філософія.

Навряд чи хтось поставить під сумнів значущість творчого доробку румунського релігієзнавця М. Еліаде, особливо у контексті загального інтересу до міфологічної проблематики, яка приваблювала філософів і мислителів XIX і XX ст. У працях М. Еліаде поняття «міф» набуває фундаментального значення, а сам міф постає в якості структурного компоненту реальності, у межах якої існує людство. Зважаючи на це зовсім не дивно, що міф (як феномен), породжений ще за часів архаїчного суспільства, і досі має величезний вплив на людське життя. Сучасний світ просякнутий (С) Легеза О. С., 2019 
міфами, які створюють міцний каркас для важливих соціальних, політичних і релігійних ідей, а також є підгрунтям для літератури, мистецтва, індивідуальних фантазій. Саме це зумовлює наш інтерес до міфу у працях М. Еліаде у двох площинах, а саме: історикофілософській, в якій розглядається саме феномен міфу як такий, представлений у дослідженнях філософа; і культурологічній, що відзначає місце і роль міфу, яким його уявляє М. Еліаде, у сучасній культурі.

Насамперед відзначимо, що творчість М. Еліаде не набула достатнього осмислення у працях вітчизняних дослідників філософii. Основна тенденція, яку можна наразі відзначити, - це інтерес до міфологічної проблематики у працях румунського мислителя в контексті дослідження феномена «міфу» як такого. Дослідження вітчизняними вченими суто міфологічної проблематики у працях М. Еліаде становить радше виключення, ніж правило. Водночас, на Заході, де дослідники більш активно вивчають творчість М. Еліаде, уже сформований певний доробок критичних праць, в яких автори приділяють увагу проблемі міфу, зокрема.

Так, серед дослідників філософії, що у своїх працях пропонують рецепцію поглядів М. Еліаде, слід зазначити тих, хто розглядає його міфологічний концепт у межах цілісного міфологічного дискурсу XX ст., або у зв'язку з концепціями інших представників названого дискурсу. Такими дослідницями $є$ I. Фрис [3] та O. І. Кириленко [2]. До науковців, які присвячують свої праці виключно проблематиці міфу у працях М. Еліаде, можна зарахувати В. П. Канарську [1] та Д. Аллена (Allen) [7]. Нарешті, низка західних дослідників звертається до міфологічної проблематики у творчості мислителя, розглядаючи іiі у контексті його релігієзнавчих ідей. До цих науковців належать Б. С. Ренні (Rennie) [11], К. Барт (Barth) [8], Е. Т. Нгкобо (Ngcobo), Ж. Бейєрс (Beyers) [9], а також О. Огуннаіке (Ogunnaike) [10].

Резюмуючи, відзначимо, що міфологічна проблематика у працях М. Еліаде потребує більш докладного дослідження, оскільки у межах вітчизняної філософії їй приділялось небагато уваги, і основні зусилля були зосереджені на комплексному дослідженні міфологічного дискурсу XX ст. У цьому полягає актуальність нашого дослідження, оскільки воно представляє рецепцію міфологі146

Institute of Philosophy of H. S. Skovoroda of NAS of Ukraine 
чного концепту М. Еліаде, і засвідчує фундаментальну роль міфу у житті сучасної людини.

Метою статті є визначення специфіки поняття «міф»у працях М. Еліаде, визначення значущості міфу, яким його вбачав дослідник, для сучасної людини.

Хоча дискусії щодо того, чи можна розглядати М. Еліаде у межах філософської проблематики все ще відкриті, його вклад у проблему розуміння і трактування поняття «міф» у другій половині XX ст. являє собою неабиякий інтерес. Незважаючи на те, що самого румунського мислителя традиційно вважають істориком релігії [10, с. 7], його праці є важливими з філософської точки зору. Він запропонував оригінальну концепцію міфу, яка корелює з ідеями інших дослідників цього явища. Зокрема, М. Еліаде продовжив розробляти юнгіанський концепт архетипів, доповнюючи i вдосконалюючи його таким чином, щоб привести у відповідність із власною теорією. Цей момент колективного розуміння сутності міфу і тяжіння до міфологізму у людському суспільстві можна чітко прослідкувати, і не виникає сумнівів стосовно того, чиї саме ідеї надихнули історика релігії. Крім цього, обидва мислителі використовують схожі приклади сучасного прояву міфів (наприклад, міф про Золотий вік). Крім К. Г. Юнга, звичайно, є й інші мислителі, ім'я яких згадується у контексті творчості М. Еліаде. Так, О. І. Кириленко [2] відзначає схожість підходів М. Еліаде і Р. Барта, хоча і наголошує, що висновки, яких дійшли ці мислителі, є суттєво різними. Водночас, підхід М. Еліаде залишається по-своєму оригінальним, а ідеї, які він проголошує, і наразі не втратили своєї значущості.

У чому полягає новизна поглядів М. Еліаде для свого часу? По-перше, дослідник розглядає міф в якості одного з визначальних феноменів на шляху розвитку людства. Міф, на його думку, не лише надає людині певні первинні орієнтири (як-от людям із первісних суспільств), але залишається певного роду дороговказом для людства впродовж його подальшого розвитку, не зважаючи на всі трансформації. У цьому сенсі ідеї М. Еліаде $\epsilon$ абсолютно протилежними теоріям, які розглядають міф як примітивні спроби пояснення світу [9]. Для М. Еліаде міф є невід'ємною частиною людського життя, за допомогою якої люди отримують знання про реаль- 
ний світ і першопричини всього, що нині існує. Більше того, навіть після тривалих процесів деміфологізації, міф, саме як певний набір концептуальних схем, так закріпився у людському житті, що ми можемо чітко прослідкувати взаємозв'язок між міфологічними сюжетами і реальними процесами, що відбуваються у світі. Тут також відзначимо, що Мірча Еліаде проводить чітку межу між міфом (як основною структурною одиницею світу) i оповідями та легендами, які насправді є просто «казками», наголошуючи на тому, що архаїчна людина без вагань відокремлювала міф (справжність) від вигадок. По-друге, слід сказати, що мислитель розкладає міф на складові, аналізуючи усі його компоненти 3 метою створення цілісної концепції даного феномена. Нарешті, дослідження румунського історика релігій є комплексним, оскільки він спирається на міфологічні сюжети, представлені у міфологіях різних народів, щоб отримати цілісну картину.

Як засвідчують дослідження I. Фрис [3], оригінальне бачення міфу М. Еліаде відрізняються від ідей інших представників міфологічного дискурсу XX ст. Деякі науковці, зокрема В. П. Канарська [1, с. 349-350], наголошують на нерозривному зв'язку життєвого шляху мислителя і формування його поглядів. I зважаючи на те, що Мірча Еліаде відомий, перш за все, як дослідник релігії, а відтак його життєвий шлях нерозривно пов'язаний iз духовними практиками, подібні припущення цілком можуть відповідати дійсності. Адже саме занурення у релігійний субстрат сприяє розширенню власного світобачення, і змінює ставлення до релігійних феноменів.

Розглянемо безпосередньо ідеї М. Еліаде стосовно сутності поняття «міф». Насамперед відзначимо, що міф для мислителя завжди постає як явище релігійне, і будь-яка міфологічна поведінка - це, водночас, поведінка релігійна [7, с. 66]. Зважаючи на це можна припустити, що і говорячи про світобачення, яке, як ми пізніше побачимо, проходить крізь призму міфологізму, для М. Еліаде воно завжди є певною мірою релігійним. Як ми вже відзначали, мислитель наділяє поняття «міф» фундаментальним значенням, говорячи, що «міф є однією із надзвичайно складних реальностей культури» [4, с. 15]. Тобто, як відзначає В. П. Канарська, міф, за М. Еліаде, «не є вигадкою, фантазією наших пращурів, він 148

Institute of Philosophy of H. S. Skovoroda of NAS of Ukraine 
може бути вирішально-важливим, навіть сакральним для усієї історії» [1, с. 350]. Натомість, він є однією із ключових структурних одиниць для конструювання реальності. Звичайно що ніхто краще за архаїчну людину не міг вловити сутність міфу, адже усе ії життя було занурене у міфологічний субстрат. Саме таке припущення зумовлює бажання М. Еліаде відкинути всі надбання людства і поглянути на міф очима первісної людини, яка ні на хвилину не сумнівається у тому, що міфи складають реальну історію світу. Так, дослідник зауважує, що «міф розглядається як сакральна оповідь, i, як наслідок, як подія, що відбулась насправді, оскільки воно завжди має відношення до певних реальностей» $[4$, с. 16]. В якості прикладу наводяться космогонічні міфи, або ж міфи про смерть, які зустрічаються в усіх культурах, і які відповідають дійсності, оскільки світ справді існує, а люди помирають. У такий спосіб сама реальність стає надійним захисником міфу і проголошує його істинність.

На думку М. Еліаде, загалом існує п'ять основних характеристик, притаманних міфу. Так, міфи складають історії подвигів надприродних створінь, є одночасно сакральними і істинними, розповідають про першопочаток (логіку виникнення) явищ, за допомогою ритуалу надають людині можливість пізнати речі, а також завжди проживаються своєю аудиторією [4, с. 28]. Щодо першого аспекту - тут нібито все зрозуміло, адже у міфах головними фігурантами завжди постають боги, герої (часто - напівбоги), а також різноманітні надприродні істоти. Звертаючись до другого пункту відзначимо, що, як ми вже згадували раніше, міф завжди сприймається аудиторією, як істинна подія, що відбулась у реальності. Це не дивно, адже у світі архаїчної людини боги і герої ходять поряд із людьми, тому усі їхні діяння, описані у міфах, не викликають сумнівів. Стосовно того, що міф - це завжди про виникнення будьякого явища, приведемо слова самого дослідника з його іншої праці: «міф є істинною історією того, що відбулося на початку часів» [5, с. 22]. Тобто кожен міф, в якому йдеться про будь-який аспект людського життя (народження, смерть, шлюбний ритуал або переродження наново), насправді описує найперший випадок в історії, коли даний процес відбувався. У такому сенсу міф і є тим самим першоджерелом, першопочатком, від якого потім утворюються 
незліченні повторення цього процесу, що перетворює його на звичне явище. Тобто, пізнаючи міф, людина пізнавала загальну логіку, яка могла б роз'яснювати різноманітні феномени. Міф мав за мету пояснити людині, яким чином вона зараз існує у межах актуальної реальності, і чому ця реальність (як і людина, що існує у ії межах) виглядає саме так. Наступний аспект міфу, який полягає у пізнанні первісних процесів через пізнання міфу, логічно випливає 3 попереднього, оскільки саме міф є тим медіатором, який розкриває людині знання про те, як відбувалось становлення різноманітних аспектів людського життя. Нарешті, людина завжди проживає ті події, що відбуваються у міфі, і тут йдеться про ритуальну складову. Мірча Еліаде приділяє ритуалам багато уваги і зазначає, що вони $є$ невід'ємною частиною міфологічної свідомості наших пращурів. Як зазначає сам дослідник, «відтворюючи міфи, вона (первісна людина. - О.Л.) наближалася до богів, і долучалася до святості» [6, с. 70]. Усі названі компоненти міфу у сукупності і визначають специфіку цього феномена, а також підкреслюють всеохоплюючий характер міфу і його значущість у людському житті.

Важливий аспект міфу, на який звертає увагу Мірча Еліаде, це специфіка повернення до міфологічного часу, який у даному контексті виступає саме як первісний час. Архаїчна людина, яка існує у межах міфологічного часу, відчуває потребу перебувати у межах сакрального часу, через постійне відтворення одних і тих самих дій [8, с. 63]. Говорячи більш докладно, «події, які передають міфи, за допомогою ритуалів переживаються усією спільнотою, або іï окремою частиною» [4, с. 84]. Ритуалістика тут виступає в якості провідника, медіатора, що переносить людину назад у часі, і дає змогу долучитись до створення світу, стати свідком того, як усе насправді відбулось. Так, розглядаючи приклад космогонічного міфу, дослідник стверджує, що «той, для кого цей міф читається, магічно вирушає до «початку Світу», стає сучасником космогонії» [6, с. 56]. Мірча Еліаде раз-у-раз наголошує на тому, що міфологічний час $є$ дуже важливим компонентом світорозуміння. На думку румунського дослідника, «найсуттєвіше вирішувалось не під час створення світу, а у міфічну епоху» [4, с. 112]. Феномен повернення до витоків усього сущого є однією з важливих функцій міфу, адже ритуал дає людині змогу відтворити практику, якій 150

Institute of Philosophy of H. S. Skovoroda of NAS of Ukraine 
присвячений міф, і провести іiі самотужки, ніби вперше в історії людства.

Згідно $з$ ідеями М. Еліаде, міф представляється значущою складовою нашого світу, оскільки він надає людям сенс існування. Як зауважує сам мислитель, функція міфу - «давати моделі, i, таким чином, надавати значущість світу і людському існуванню» [4, с. 146]. Іншими словами, основна роль міфу полягає у тому, щоб робити світ впорядкованим, структурованим. Люди, наділені міфологічною свідомістю, відрізняються більшою чутливістю до усіх причинно-наслідкових зв'язків, оскільки міфи відкривають їм, що насправді усе, що існує у цьому світі, має свою причину. Це допомагає людині знайти відповіді на екзистенційні питання, які супроводжують iї 3 давніх давен. Як стверджує Б. С. Ренні [11, с. 83], міф перетворює звичайне сприйняття світу на релігійне. Отже, міф як такий відкриває людині інший вимір світобачення, що у до-міфологічний час був для неї закритий. М. Еліаде стверджує, що «міф розмовляє $з$ людиною, і для того, щоб зрозуміти цю мову, достатньо знати міфи і вміти розгадувати символи» [4, с. 143]. Тобто знання міфу допомагає людині орієнтуватись у цьому світі, не відчувати себе у вирі хаосу без будь-якої підтримки. Також зазначимо, що міфи не лише пояснюють людині, як влаштований світ, вони також запевняють іiі, що вона спроможна усе це повторити самотужки. Так, Мірча Еліаде зазначає: «міфи пояснюють їй (первісній людині. - О.Л.) світ і спосіб ії існування у світі, але, що є більш важливим, згадуючи і відтворюючи їх, вона стає спроможною відтворити те, що боги або герої зробили на початку» [4, с. 23]. Тобто людина наново відтворює ті практики і ритуали, які на початку світу започаткували міфологічні персонажі. Це $\epsilon$ своєрідним наближенням до богів та героїв, і саме через міф людина рідниться з ними, відчуває себе причетною до легендарних подій. Відтак, міф надає підгрунтя для самореалізації людини у світі.

Отже, міф у М. Еліаде виконував своєрідну роль вчителя, створюючи необхідні людині моделі поведінки. На думку румунського мислителя, саме завдяки міфологічним образам героїв та богів людина розуміла, які саме дії є доречними, а які - недоречними за певних обставин. I, що важливіше, ця тенденція зберіга- 
ється і донині у відлунні міфологічного в житті людини. Так, розглядаючи розвиток міфологічних ідей, Мірча Еліаде відзначає: «реальні та уявні герої відіграють важливу роль у формуванні європейського юнацтва: персонажі пригодницьких оповідань, герої війни, улюбленці екрану і так далі» [5, с. 33-34]. Тобто, румунський мислитель фіксує і те, що навіть трансформуючись, міф продовжує відігравати важливу роль у суспільстві.

Мірча Еліаде не лише описує значущість міфу для людини, що іiі життя глибоко просякнуте міфологізмом, але й стверджує, що міфи продовжують відігравати важливу роль у сучасному світі. Тут не йдеться про те, що люди продовжують вірити у богів та химерних надприродних істот. Звичайно, сучасна людина вже не сприймає міфи на тому рівні, як це робить людина архаїчна, і трансформовані міфи, які нам наразі відомі, не мають нічого спільного 3 розповідями про давніх богів та героїв. Міф насправді $є$ чимось на зразок каркасу, способом існування актуальної реальності. Сучасність створює власні міфи, але вони є лише спадкоємцями архаїчних міфів (якими їх бачить М. Еліаде). Він наводить приклади такого «відлуння» міфологічного світосприйняття у житті людини після процесів «деміфологізації», розпочатих ще за давніх часів, під час переходу від усної до писемної творчості. У якості основних течій можна зазначити релігію, політику, культуру, а також прояв міфологізму на індивідуальному рівні. Так, як і свого часу К. Г. Юнг, Мірча Еліаде наводить християнство в якості прикладу такого десакралізованого міфу, визначаючи і самого Iсуса Христа як міфологічного (але дещо трансформованого) персонажа [4].

Мистецтво та література стають ще одним важливим медіатором, який допомагає людині підтримувати зв'язок із міфологією архаїчних часів. Мислитель зауважує: «секуляризована і деміфологізована грецька релігія та міфологія збереглись у європейській культурі перш за все тому, що були виражені у видатних творах літератури і мистецтва» [4, с. 160]. А щодо політичних міфів сучасності, то Мірча Еліаде звертається до марксистської ідеології і комуністичних ідеалів, посилаючись на них, як на наново відтворений міф про Золотий вік. Він відзначає, що Маркс «продовжує один із найбільш значущих есхатологічних міфів Середземномор'я i Середнього Півдня, а саме: роль рятівника, яку грає Справедли152

Institute of Philosophy of H. S. Skovoroda of NAS of Ukraine 
вий... страждання якого мають змінити онтологічний статус світу» [5, с. 25]. Поряд із комуністичним міфом стоїть націоналсоціалістична традиція, яку, одначе, дослідник вважає не настільки розробленою [5]. Отже, два названі міфи складають основну частину політичної міфології сучасного М. Еліаде світу, оскільки у них найбільш чітко виокремлено міфологічні мотиви. На індивідуальному рівні міфи проявляються у людській уяві, сновидіннях i фантазіях, а їхнє відлуння збереглось у традиціях, які наразі здаються абсолютно звичайними. В якості прикладу дослідник наводить святкування Нового Року, народження дитини, переїзд до нової будівлі або будівництво дому [5]. Усі ці приклади яскраво ілюструють те, що міф від початку часів увійшов у людське життя i надійно у ньому закріпився.

Якщо розглянути ідеї, висловлені М. Еліаде, відносно нашої сучасності, побачимо, що вони все ще є актуальними. Наприклад, розглядаючи концепцію міфів як паттернів поведінки, зазначимо, що сьогодні у популярній культурі з'являється безліч образів, які продукують «бажаний» концепт особистості та поведінки. Наприклад, концепція супергероїв, наразі така популярна в усьому світі, цілком відповідає згаданій тенденції, оскільки породжує в юнацтва бажання наслідувати цих персонажів. Крім цього, існує безліч популярних персонажів із різноманітними типажами, які дають величезній кількості людей можливість або ототожнювати себе з ними, або сприймати цих персонажів як взірець для поведінки, певний ідеал. Тобто вони виконують ту функцію, яка за архаїчних часів покладалась на міфологічних персонажів. Це засвідчує, що міфологія і досі відіграє значну роль у людському світосприйнятті, сприяє формуванню людини, як особистості.

Також відзначимо, що ті аспекти сучасного життя, на формування і виникнення яких, на думку М. Еліаде, вплинув міф, і досі лишаються під владою міфологізму. Так, християнство продовжує продукувати міфологічні ідеї (які відзначили М. Еліаде i К. Г. Юнг). Релігія у цілому, як дитина та спадкоємиця міфології, i досі зберігає багато міфологічних сюжетів і постатей, трансформуючи їх згідно із запитами власної культурної парадигми. Стосовно політичних ідей, що грунтуються на міфології, зазначимо, що актуальна для М. Еліаде комуністична концепція і досі має чимало 
прихильників у всьому світі, а у деяких країнах постає в якості провідної ідеології (Китай - найяскравіший цьому приклад). Вона справді, як і передбачив М. Еліаде, стала однією із ключових для сучасного світу. Щодо зв'язку між міфом та літературою, відзначимо, що наразі справді є автори, які використовують міфологічні сюжети в якості підгрунтя для своїх праць, а також ті, хто обирає загальні міфологічні концепції (а не сюжети, що не менш важливо), надбудовуючи на них події, актуальні для сучасності. До того ж, у літературі зараз набуває популярності ідея реміфологізації, за якою звичні міфологічні сюжети переосмислюються у контексті інших культурних парадигм. Також відзначимо, що більшість традицій, які згадує М. Еліаде у зв'язку з провідною роллю міфу, і донині залишаються актуальними i, по суті, є новітніми ритуалами. Прояви міфологізму на індивідуальному рівні також лишаються незмінними. Отже, як бачимо, наразі міф лишається фундаментальною одиницею для конструювання реальності і окремих іiі аспектів, як і зазначав свого часу М. Еліаде.

Отже, для М. Еліаде міф є однією з визначальних складових актуальної реальності, оскільки він допомагає людині структурувати процеси навколишнього світу, а також задовольняє ії екзистенційні потреби. Ще одна важлива функція міфу - впровадження паттернів поведінки, які наслідує людина, яка ці міфи сприймає. Цей аспект проявлявся ще в архаїчних суспільствах, а наразі знаходить своє відображення, зокрема, у сучасних персонажах кінематографу та літератури, які також є прикладами для наслідування. Мислитель виокремлює п'ять основних аспектів міфу, які рівною мірою визначають унікальність цього явища. По-перше, за М. Еліаде, кожен міф є історією про подвиги надприродних створінь. По-друге, кожен міф є істинним у світоглядному конструюванні архаїчної людини, і вона не має жодного сумніву щодо того, що все так і відбувалось насправді. По-третє, міф розповідає, як 3'явилось те чи інше явище, тобто надає знання про першопочаток, пошук якого завжди був актуальним для людини. По-четверте, міф дає людині змогу пізнати усі ті процеси, які він відтворює. Нарешті, міф завжди проживається аудиторією, і тут відзначається провідна роль ритуалу, який і повертає людину назад у минуле, до початку світу, відкриваючи їй доступ до міфологічного часу. Також за 
допомогою ритуалу людина має змогу вперше відтворити той чи інший процес (наслідуючи міфологічних персонажів). У сучасному світі присутнє відлуння секуляризованої міфології, оскільки саме архаїчні міфи були тим підгрунтям, завдяки якому з'явились провідні релігійні і політичні течії, витвори літератури і мистецтва, традиції та індивідуальні відчуття, близькі міфологічному світосприйняттю. Це робить міф одним із фундаментальних концептів у контексті людського існування у сучасному світі, і засвідчує, що навіть попри розвиток науки і деміфологізацію, більшість аспектів сучасного життя і досі мають відбиток міфу.

Наступні дослідження даної проблематики можуть бути пов'язані 3 подальшим аналізом культурологічних феноменів та процесів, які чітко фіксують прояви міфологічного у сучасному світі.

\section{ЛITEPATУРА}

1. Канарська В. П. Формування і розвиток вчення Мірча Еліаде про міф // Наукові праці Кам'янець-Подільського національного університету імені Івана Огієнка. Філологічні науки. 2013. № 34. C. 349-351.

2. Кириленко Е. И. Р. Барт и М. Элиаде: два опыта истолкования мифа // Вестник Томского государственного университета. 2007. № 297. C. 66-70.

3. Фрис I. Міфологічні концепції XX ст.: огляд проблеми // Київські полоністичні студії. 2012. № 19. С. 377-382.

4. Элиаде М. Аспекты мифа. М. : Академический Проект, 2010. 251 с.

5. Элиаде М. Мифы. Сновидения. Мистерии. М. : REFL-book, 1996. $288 \mathrm{c}$.

6. Элиаде М. Священное и мирское. М. : Изд-во МГУ, 1994. 144 с.

7. Allen D. Myth and Religion in Mircea Eliade. New York : Routledge, 2013. 386 p.

8. Barth C. In illo tempore, at the center of the world: Mircea Eliade and religious studies' concepts of sacred time and space. Historical Social Research. 2013. Vol. 38. No. 3. P. 59-75.

9. Ngcobo E. T., Beyers J. Is it still possible to study religion religiously today? Mircea Eliade's religious apologetic account. Verbum Eccles. 2013. Vol.34. No.1. URL: http://www.scielo.org.za/scielo.php?script= sci_arttext\&pid=S2074-77052013000100018. 
10. Ogunnaike O. Myth and the Secret of Destiny: Mircea Eliade's Creative Hermeneuticsand the Yorùbá Concept of Orí. Journal of Comparative Theology. 2012. Vol. 3. Iss. 1. P. 4-42.

11. Rennie B. S. Mircea Eliade and the Perception of the Sacred in the Profane: Intention, Reduction, and Cognitive Theory. Temenos Nordic Journal of Comparative Religion. 2007. Vol. 43. No. 1. P. 7398.

\section{REFERENCES}

1. Kanarska, V. P. (2013). Formation and Development of Mircea Eliade's Concept of Myth. Naukovi Pratsi Kamianets-Podilskoho Natsionalnoho Universytetu Imeni Ivana Ohiienka. Filolohichni Nauky. (KamianetsPodilskyi National Ivan Ohiienko University Research Papers. Philo?ophical Studies), 34, 349-351. [In Ukrainian].

2. Kirilenko. E. I. (2007). R. Barthes and M. Eliade: Two Interpretations of Myth. Vestnik Tomskogo Gosudarstvennogo Universiteta (Tomsk National University Journal), 297, 66-70. [In Russian].

3. Frys, I. (2012). 20 ${ }^{\text {th }}$ Century Mythological Concepts: an Overview. Kyivski Polonistychni Studii (Kyiv Polonian Studies), 19, 377-382. [In Ukrainian].

4. Eliade, M. (2010). Aspects of Myth. Moscow: Akademicheskiy Proyekt. [In Russian].

5. Eliade, M. (1996). Myths, Dreams, and Mysteries. Moscow: REFLbook. [In Russian].

6. Eliade, M. (1994). The Sacred and The Profane. Moscow: Izdatelstvo MGU. [In Russian].

7. Allen, D. (2013). Myth and Religion in Mircea Eliade. New York: Routledge, 2013.

8. Barth, C. (2013). In Illo Tempore, at The Center of The World: Mircea Eliade and Religious Studies' Concepts of Sacred Time and Space. Historical Social Research, 38(3), 59-75.

9. Ngcobo, E. T. \& Beyers, J. (2013). Is It Still Possible to Study Religion Religiously Today? Mircea Eliade's Religious Apologetic Account. Verbum Eccles, 34(1). Retrieved from http://www.scielo.org.za/scielo.php?script=sci_arttext\&pid=S207477052013000100018.

10. Ogunnaike, O. (2012). Myth and The Secret of Destiny: Mircea Eliade's Creative Hermeneuticsand the Yorùbá Concept of Orí. Journal of Comparative Theology, 3(1),4-42. 
11. Rennie, B. S. (2007). Mircea Eliade and The Perception of The Sacred in The Profane: Intention, Reduction, and Cognitive Theory. Temenos Nordic Journal of Comparative Religion, 43(1), 73-98.

\title{
Oleksandra Legeza
}

Post-Graduate Student (PhD) of the Department of Philosophy

Oles Honchar Dnipro National University

Dnipro, Ukraine, e-mail: volansandvela@gmail.com

ORCID: https://orcid.org/0000-0002-0329-4329

\section{Eliade's Concept of Myth}

\begin{abstract}
The paper deals with Mircea Eliade's concept of myth. The study aims to analyze the core features of the myth presented in Eliade's works and to explain the essentiality of myth in the modern world. The main peculiarity of M. Eliade's approach is that he discusses myth considering its value for people of archaic cultures since these people understood the fundamentality of this phenomenon. According to Eliade, myth is one of the components of reality and is sacred and veridical for primitive people. In addition, members of primitive cultures distinguish myth from the fictional stories, which means they are able to differentiate truth from fantasies, and myths are always true. Eliade defines five main features of the myth. Firstly, myths are stories about the exploits of gods and heroes. Secondly, myths are both sacred and true. Thirdly, myths are the narratives about the origin of all processes and phenomena. Fourthly, by means of myth, the one can cognize these processes themselves. Finally, the audience always lives the myth by means of the ritual. Furthermore, rituals play a great role in Eliade's mythological concept since they allow the one to live in mytho?ogical time, instead of historical time. The author of the paper argues that Eliade's myth satisfies the one's existential demands allowing him (her)to structuralize the world and to find a fulcrum. Additionally, myths and their modern equivalents create important behavioral patterns. Considering the importance of myths in modernity, the author of the article comes to the concl?sion that such important phenomena as religion (including Christianity), politics, literature, and arts, as well as the traditions, dreams, and imagination, are derived from myths. Therefore, despite the process of demythologization, myths still influence the lives of modern people.
\end{abstract}


Keywords: M. Eliade, myth, mythology, mythological discourse, philosophy.

\section{Александра Легеза}

аспирантка кафедры философии

Днепровский национальный университет им. О. Гончара

2. Днепр, Украина, e-mail: volansandvela@gmail.com

ORCID: https://orcid.org/0000-0002-0329-4329

\section{Концепция мифа в работах М. Элиаде}

\section{Аннотация}

Исследована концепџия мифа в работах М. Элиаде. Установлено, что М. Элиаде рассматривает миф как неотъемлемый структурный компонент реальности культуры, отделяя его от «ненастоящих» рассказов. Дана характеристика основных составляющих мифа в работах М. Элиаде. Показано, что, по мнению М. Элиаде, миф возвращает человека к истокам мира, отвечает его экзистенциальным запросам, и предоставляет человеку необходимые паттерны поведения. Доказано, что даже после прочессов демифологизаиии, миф, каким он представляется румынскому исследователю, играет ключевую роль в жизни человека, поскольку способствует появлению важных традиций, политических и религиозных течений, произведений литературы и искусства, а на индивидуальном уровне проявляется в виде фантазий и сновидений.

Ключевые слова: М. Элиаде, миф, мифология, мифологический дискурс, философия. 